\title{
GROWTH PERFORMANCE AND BLOOD INDICES OF BROILER FINISHER BIRDS FED ENZYME-FORTIFIED (MAXI GRAIN) RICE MILLING WASTE
}

\author{
*Esiegwu, A. C. and Okonkwo, V. N. \\ Department of Animal Science and Fisheries, \\ Imo State University, P. M. B. 2000, Owerri, Nigeria. \\ *Corresponding Author: Email - arthuresiegwu@yahoo.com
}

\begin{abstract}
An experiment was conducted to evaluate the effect of enzyme fortified (Maxi grain) rice milling waste on the performance and blood indices of finisher broilers. The enzyme fortified (Maxi grain) rice milling waste was used to make broiler finisher diets at 0.0\%, 5.0\%, 10.0\%, and $15.0 \%$ inclusion levels, respectively. These were then used to raise groups of 30 broiler finishers in a completely randomized design (CRD) for 4 weeks (28 days). At the end of the 28 days feeding trial, 3 birds were selected from each group for blood indices evaluation. The average daily weight gain and average daily feed intake showed no treatment effect $(P>0.05)$. The feed conversion ratio was significantly increased $(P<0.05)$ at $10 \%$ and $15 \%$ dietary levels. The feed cost per $\mathrm{kg}$ meat was lowest at $15.0 \%$ dietary levels. There were no treatment effect on all the haematological and some serum biochemical indices analysed. It was therefore concluded that enzyme fortified (Maxi grain) rice milling waste can serve as feed ingredient at $10 \%-15 \%$ dietary levels due to cost effectiveness.
\end{abstract}

Keywords: Performance, blood indices, broiler finisher, enzyme, rice milling waste https://dx.doi.org/10.4314/jafs.v16i1.3

\section{INTRODUCTION}

There is no doubt that the cost of providing feed and drugs in livestock and poultry industry in Nigeria are steadily increasing (Esiegwu et al., 2013). Some agro-industrial by-products, if carefully processed and incorporated in animal rations could supply some energy, proteins, vitamins and minerals that would enhance performance and reduce cost of production. Agroindustrial by-products are important feed components in poultry diets in Nigeria mainly due to the increased competition for the conventional ingredients by humans and the food industries (Iyayi and Davies, 2005). Rice milling waste (RMW) is one of those by-products that could be of value to livestock and poultry.

Rice milling waste, the by-product of rice milling process which contains the bran, polishing, husk and small quantities of broken grains constitutes about $40 \%$ of paddy rice and is available in large quantities in the major rice growing areas of Nigeria (Dafwang and Damang, 1995). The Journal of the Faculty of Agriculture and Veterinary Medicine, Imo State University Owerri website: www ajol.info 
main by-products of rice milling are rice hulls or husk, rice bran and broken rice of which the rice husks, the major part of RMW contains about $3.66 \mathrm{kCal} / \mathrm{g}$ energy, $5.25 \%$ crude protein and $33.1 \%$ fibre (IRRI, 2008). Adeyina et al. (2016) reported the proximate composition of rice milling waste to contain $91.09 \%$ dry matter, $7.32 \%$ crude protein, $1.82 \%$ ether extract and $18.00 \%$ crude fibre. Similarly, Ani et al. (2013) reported that rice milling waste contains $93.65 \%$ dry matter, $6.35 \%$ moisture, $5.25 \%$ crude protein, $33.18 \%$ crude fibre, $3.9 \%$ ether extract, $23.15 \%$ ash and $28.17 \%$ nitrogen free extract. The use of rice milling waste in monogastric animal feeding is not very popular because of its high fibre content and the presence of some anti-nutritional factors that inhibit the effective utilization of nutrients. High fibre content in diet interferes with nutrient availability at tissue level (Adejinmi, 2007). Rice milling waste is known to contain anti nutritional factors such as phytic acid, lectin and trypsin inhibitors (Liener, 1986). Broiler, a simple stomach animal does not tolerate high level of fibre. There is need therefore, to employ the services of enzyme in their diet in order to enhance the breakdown of the non-starch polysaccharides (NSPs) present in fibre.

Enzymes have been known to improve livability, feed conversion ratio and weight gain in broiler chickens (Okorie et al., 2017). Enzymes also improve the productive value of fiber feedstuffs (Augustine et al., 2011). Maxigrain is an exogenous enzyme that contain blend of most relevant digestive enzymes non-soluble polysaccharides (NSPs) enzymes and phytase that bring about efficient utilization of wide range of agro-industrial by-products like cassava peel meal (Aguihe et al., 2014). Maxigrain is a multi-enzyme compound of B-glucanase, xylanase, phytase, arabinoxylanase and a mixture of yeast and minerals, and it originates from the bacteria Aspergillus oryzae (Alu et al., 2012; Ogungbesan et al., 2014).

The study therefore was aimed at investigating the growth performance and blood indices of finisher broiler birds fed enzyme-fortified (maxi grain) rice milling waste.

\section{MATERIALS AND METHODS}

This experiment was carried out at the poultry unit of teaching and research farm, Imo State University Owerri, which is located within the South-Eastern agro-ecological zone of Nigeria. Owerri lies between latitude $5^{0} 29^{\prime}$ North and longitude $7^{0} 20^{\prime}$ East. It is about $91 \mathrm{~m}$ above sea level with annual rainfall, temperature and humidity ranging from $1,500 \mathrm{~mm}$ to $2,200 \mathrm{~mm}, 20.0-$ $27.5^{\circ} \mathrm{C}$ and $75-90 \%$, respectively (Accuweather, 2015).

The rice milling waste was bought from a reputable source in Ekeonuwa market in Owerri, Imo State. The enzyme - Maxigrain was incorporated into the rice milling waste at the rate of $0.01 \%$ inclusion levels for all the treatment diets except the control. Samples of the rice milling waste were taken to the laboratory for proximate analysis according to AOAC (2010). Before the incorporation of the enzymes, an enzyme potency test was carried out by dissolving the enzymes 
in 50 centilitre of water. This was poured into the cellulose in a container and allowed to stand for 12 hours in which the cellulose dissolved showing that the enzyme was active (positive). Four finisher broiler diets were compounded, incorporating the rice milling waste fortified with enzyme - Maxigrain at $0 \%, 5.0 \%, 10.0 \%$ and $15.0 \%$ inclusion levels respectively, partly replacing maize in the control diet. The diets were thus designated as $\mathrm{T}_{0}, \mathrm{~T}_{5.0}, \mathrm{~T}_{10.0}$ and $\mathrm{T}_{15.0 \text {, }}$ respectively. The ingredient and calculated nutrient composition of the diets are shown in Table 1.

One hundred and twenty (120) 4 - weeks old Marshal broiler chicks bought from a reputable dealer in Owerri were used for the trial. The birds were randomly divided into four groups of 30 broilers and each group randomly assigned to one of the four treatment diets in a completely randomized design (CRD). Each group was further subdivided into three replicates of 10 broilers each and each replicate housed in a deep litter compartment measuring $1 \mathrm{~m} \times 1.5 \mathrm{~m}$. Feed and water were provided ad libitum. The trial lasted for 28 days. The birds were weighed at the beginning of the experiment to obtain their initial body weights and weekly, thereafter. Daily feed intake was determined by subtracting the weight of leftover feed from the weight of the feed given the previous day. Data were collected on feed intake, body weight gain and feed conversion ratio. Feed conversion ratio was calculated by dividing the average daily feed intake by average daily weight gain. Blood samples were collected from 3 birds per treatment at the end of the experiment from the wing web of the birds using syringe and needle and placed in the specimen bottles with EDTA (Ethylene Diamine Tetra Acetate) for haematological studies and some placed in the specimen bottles without EDTA for biochemical studies. Haematological and some serum biochemical indices were analysed according to the method outlined by Ochie and Kolhatkar (2000).

Data collected were subjected to analysis of variance using the SPSS software (2012). Where analysis of variance indicated significant treatment effects, means were compared using Duncan's New Multiple Range Test (DNMRT) (SPSS, 2012).

\section{RESULTS AND DISCUSSION}

\section{Proximate composition}

The proximate composition of the rice milling waste (RMW) are shown in Table 2. The crude protein ( $\mathrm{CP}, \% \mathrm{DM})$, crude fibre (CF), ether extract (EE), ash and nitrogen free extract (NFE) were close to the values $5.25 \% \mathrm{CP}, 33.18 \% \mathrm{CF}, 3.9 \% \mathrm{EE}$ and $28.17 \%$ NFE reported by Ani et al. (2013). However, the proximate values varied more from the report of Olusiyi and Wafar (2017) containing $8.75 \% \mathrm{CP}, 36.99 \% \mathrm{CF}, 20.12 \%$ ash, $5.14 \% \mathrm{EE}$, and $25.66 \%$ NFE. These variations in nutrient compositions could be due to climatic conditions, edaphic factors as well as methods of processing and laboratory analytical procedures (Taiwo et al., 2005). 
The performance characteristics of finisher broilers fed enzyme fortified rice milling waste are shown in Table 3. The data showed that there were no significant treatment effect $(\mathrm{P}>0.05)$ on the average daily feed intake and average daily weight gain. The feed conversion ratio was significantly increased $(\mathrm{P}<0.05)$ at $10 \%$ and $15 \%$ dietary levels. The feed cost per kg meat was lowest at $15.0 \%$ dietary levels.

Manafi et al. (2011) reported that broiler finishers fed enzyme supplemented diets have increased feed intake due to increased nutrient digestibility, however, Oladunjoye and Ojebiyi, (2010) reported decreased feed intake for broilers on enzyme supplemented diets as a result of fulfilling their nutrient requirements by taking less amount of feed. Generally speaking, consumption is a function of the physiological state of the birds, the age of the birds, the breed, the season, the nature and palatability of the feed. The findings in this study is in line with the report of Abu et al. (2011) who observed no significant difference across dietary treatments for daily feed intake, weight gain and feed conversion ratio for broiler finishers fed diets supplemented with Roxazyme $G$ and exogenous phytase but contradicted the report of Ani et al. (2013) for enzyme supplemented rice milling waste fed to broiler chicks in starter ration. According to Ani et al. (2013), it resulted in a significant $(\mathrm{P}<0.05)$ reduction in feed intake and enhanced significantly $(\mathrm{P}<0.05)$ the performance of the broiler chicks that consumed such enzyme supplemented diets.

Data on the haematological and some serum biochemical indices of broiler finishers fed enzyme fortified rice milling waste are shown in Tables 4. The result showed that there were no treatment effect $(\mathrm{P}>0.05)$ on all the haematological and some serum biochemical indices analysed. This was an indication that rice milling waste fortified with maxigrain enzyme had no deleterious effect on the blood indices of broiler finishers and could serve as a suitable energy substitute in broiler finisher diet.

\section{CONCLUSION AND RECOMMENDATION}

It was concluded that for cost effectiveness in broiler production, $10.0 \%$ to $15.0 \%$ enzyme fortified rice milling waste could be incorporated in broiler finisher diet. The diet did not exhibit any detrimental signs to the blood indices of the birds.

Therefore, it was recommended that the use of enzyme fortified rice milling waste as an alternative energy source in the diet of broilers should not exceed $15.0 \%$ inclusion level because of its cost effectiveness at this level. 


\section{REFERENCES}

Abu, O. A., Sodeinde, A. O., Ehalodu, J. O., Olomola, O. O. and Babayemi, O. J. (2011). Performance and carcass characteristics of broiler finishers fed diets supplemented with Roxaze G and exogenous phytase. Trop. Anim. Prod. Invest. 14 (1): $01-06$.

Accuweather(2015).Weather for Owerri, Nigeria. http://www.accuweather.com/en/ng/owerri/253317/weather-forecast/253317. Retrieved on November 15, 2015.

Adejinmi, O. O., Hamzar, R. A. and Fapohinda, J. B. (2007). Performance and nutrient digestibility of rabbit. Nigeria Journal of Animal production. 34 (1): 63 - 68.

Adeyina, A. O., Akanbi, A. S., Solihu, A. O. and Oyebode, R. J. (2016). Effect of rice milling waste based diets on performance and physiological parameters in female rabbits. Nig. J. Agriculture, Food and Environment. 12 (3): 119 - 122.

Aguihe, P. C., Kehinde, A. S., Fatokun, B. O., Omotugba, S. K. and Ashifat, A. A. (2014). Effect of enzyme supplementation on haematology and serum biochemistry of broiler finishers fed cassava peel meal based diets. Trop. Anim. Prod. Invest. 17 (1): 47 - 51.

Alu S. E., Tulen, C. D., Kaankuka, F. G. and Carew, S. N. (2012). Meat quality of female quails fed low or high fiber diets supplemented with Maxigrain enzyme. Pakistan Journal of Nutrition, 11(12): 1101 - 1106.

Ani, A. O., Kalu, I., Ugwuowo, L. C. and Iloh, E. A. (2013). Dietary effect of rice milling waste and supplementary enzyme on performance of broiler chicks. Afr. J. Biotechnol. Vol. 2 (34): $5326-5332$.

AOAC (2010). Official methods of analysis. $19^{\text {th }}$ edition. Association of official Analytical chemists. Washington D. C. USA.

Augustine, C. B., Yakubu, S. M., Yahaya, A. Midau, A., Kiborn and Udoyong, A. O. (2011). Performance of broiler chicken fed enzymes supplemented cassava peel meal based diets. International Journal of Sustainable Agric. 3 (1): 01 - 04.

Dafwang, I. I. and Damang, P. (1995): Rice offal in finishing diets for broilers. Journal of Animal Production Research 15 (1) : 131 - 139.

Esiegwu, A. C., Emenalom, O. O., Enyenihi, G. E., Okoli, I. C. and Udedibie, A. B. I. (2013). The performance and egg quality characteristics of layers fed diets containing graded levels of Garcinia kola seed meal. Nigerian Journal of Animal Production Vol. 40 (Number 2): 39 - 44.

Iyayi, E. A. and Davies, B. I. (2005). Effect of enzyme supplementation of palm kernel meal and brewer's dried grain on the performance of broilers. International Journal of Poultry Science 4(2): $76-80$.

Liener, I. E. (1986).Trypsin inhibitors: Concern for human nutrition. J. Nutr. 116 (5): 920 - 923.

Manafi, M. Hossein, B. and Mohammad, Y. (2011). Effect of polyzyme in broilers fed with corn(Zea mays L.) bran-based diets. Advances in Environmental Biology, 5(7): 1651 1655 .

Journal of the Faculty of Agriculture and Veterinary Medicine, Imo State University Owerri website: www ajol.info 
Ochie, J. and Kolhatkar, A. (2000). Medical laboratory science. Theory and practice. Tata McGraw-Hill company limited New Delhi.

Ogungbesan, A. M., Adeleke, G. A., Fasina, O. E. and Adeyemi, K. A. (2014). Effect of Maxigrain supplemented Gliricidia sepium (JACQ) leaf meal on performance characteristics and nutrient utilization in laying hens (Gallus domesticus brizzen). Journal of Science and Research, 3(3): 04 - 06.

Okorie, K. C., Esiegwu, A. C. and Okonkwo, V. N. (2017). Efect of enzyme (Zympex 0.8) supplementation on performance and blood indices of finisher broilers fed diets containing toasted Mucuna sloanei meal. Int'l. Journal of Agric. And Rural Dev. Volume 20(1): $2986-2992$.

Oladunjoye, I. O. and Ojebiyi, O. O. (2010). Performance characteristics of broiler chicken (Gallus gallus) fed rice (Oriza sativa) bran with or without Roxazyme G2G. International Journal of Animal and Veterinary Advances, 2(4): 135 - 140.

Olusiyi, J. A. and Wafar, R. J. (2017). Performance of broiler chickens fed graded dietary levels of rice milling residue as a fibre source. Asian Research Journal of Agriculture, 4(1): 1 6.

SPSS (2012). Statistical package for social sciences, version 21. USA IBM Corporation.

Taiwo, A. A., Adejuyigbe, A. D., Adeowale, J. A., Osbotan, J. S. and David, O.O. (2005) Performance and nutrient digestibility of weaned rabbits fed forages supplemented with concentrates. Nigerian Journal of Animal Production. 32(1): 74 - 78. 


\section{APPENDIX}

Table 1: Ingredient and calculated nutrient compositions of the experimental diets

\begin{tabular}{|c|c|c|c|c|}
\hline \multirow{3}{*}{ Ingredients } & \multicolumn{4}{|c|}{ Dietary levels of enzyme fortified RMW } \\
\hline & \multirow[t]{2}{*}{$\mathrm{T}_{1}(\mathbf{0 . 0 \%})$} & \multirow[t]{2}{*}{$\mathbf{T}_{2}(5.0 \%)$} & \multirow{2}{*}{$\mathrm{T}_{3}(\mathbf{1 0 . 0 \%}$} & \multirow{2}{*}{$\begin{array}{l}T_{4}(15.0 \\
)\end{array}$} \\
\hline & & & & \\
\hline Maize & 55 & 50 & 45 & 40 \\
\hline Rice milling waste & 0 & 5 & 10 & 15 \\
\hline Soya bean meal & 16 & 16 & 16 & 16 \\
\hline Groundnut cake & 5 & 5 & 5 & 5 \\
\hline Palm kernel cake & 10 & 10 & 10 & 10 \\
\hline Wheat offal & 5 & 5 & 5 & 5 \\
\hline Fish meal & 2 & 2 & 2 & 2 \\
\hline Blood meal & 2 & 2 & 2 & 2 \\
\hline Bone meal & 4 & 4 & 4 & 4 \\
\hline *Vitamin premix & 0.25 & 0.25 & 0.25 & 0.25 \\
\hline Common salt & 0.25 & 0.25 & 0.25 & 0.25 \\
\hline L-Lysine & 0.25 & 0.25 & 0.25 & 0.25 \\
\hline Di-Methionine & 0.25 & 0.25 & 0.25 & 0.25 \\
\hline \multicolumn{5}{|c|}{ Calculated chemical compositions of experimental diets } \\
\hline Crude protein & 19.66 & 19.52 & 19.37 & 19.22 \\
\hline Crude fibre & 4.38 & 5.75 & 7.14 & 7.84 \\
\hline Ether extract & 4.27 & 4.09 & 3.92 & 3.74 \\
\hline Calcium & 1.60 & 1.60 & 1.60 & 1.60 \\
\hline Phosphorus & 1.13 & 1.12 & 1.10 & 1.01 \\
\hline Lysine & 1.21 & 1.20 & 1.19 & 1.11 \\
\hline Methionie & 0.61 & 0.60 & 0.58 & 0.52 \\
\hline Metabolizable Energy $\mathrm{kcal} / \mathrm{kg}$ & 2848.04 & 2756.20 & 2664.35 & 2572.51 \\
\hline \multicolumn{5}{|c|}{$\begin{array}{l}\text { *Provided the following per kg of feed; vitamin A, 1000iu; vitamin D3, 1500iu; vitamin E, } \\
\text { 51mg; vitamin K, 2mg; Riboflavin, 3mg; Pantothenic acid, 10mg; Nicotinic acid, 25mg; } \\
\text { Choline, 350mg; Folic acid, 1mg; Mg, 56mg; Iodine, 1mg; Fe, 20mg; Zn, 50mg; Co, 1.25m }\end{array}$} \\
\hline \multicolumn{5}{|c|}{ Table 2: Proximate composition of rice milling waste } \\
\hline Nutrient \% DM & \multicolumn{2}{|c|}{ Composition } & & \\
\hline Crude fibre & \multicolumn{2}{|c|}{30.29} & & \\
\hline Crude protein & \multicolumn{2}{|l|}{6.02} & & \\
\hline Ash & \multicolumn{2}{|l|}{24.0} & & \\
\hline
\end{tabular}

Journal of the Faculty of Agriculture and Veterinary Medicine, Imo State University Owerri website: www ajol.info 
Journal of Agriculture and Food Sciences

Volume 16 Number 1, April 2018 pp.

Esiegwu, A. C. and Okonkwo, V. N.

$\begin{array}{ll}\text { Ether extract } & 24-32 \\ \text { Moisture } & 3.81 \\ \text { Nitrogen free extract } & 6.00 \\ \text { Dry matter } & 29.88 \\ \text { ME (Kcal/kg) } & 93.00 \\ \end{array}$

Table 3: Performance of broiler finishers fed rice milling waste fortified with Maxigrain enzyme

\begin{tabular}{|c|c|c|c|c|c|c|c|}
\hline \multirow{2}{*}{\multicolumn{2}{|c|}{ Parameters }} & \multicolumn{5}{|c|}{ Dietary Treatments } & \multirow[b]{2}{*}{ SEM } \\
\hline & & $\begin{array}{c}\mathrm{T} 1 \\
(\mathbf{0 \%}) \\
\end{array}$ & \multicolumn{2}{|c|}{$\begin{array}{c}\mathrm{T} 2 \\
(\mathbf{5 . 0 \%})\end{array}$} & $\begin{array}{c}\text { T3 } \\
(\mathbf{1 0 . 0 \%})\end{array}$ & $\begin{array}{c}\text { T4 } \\
(\mathbf{1 5 . 0 \%})\end{array}$ & \\
\hline \multicolumn{2}{|c|}{ Average initial body weight $(\mathrm{g})$} & 770 & 750 & & 730 & 760 & 27.00 \\
\hline \multicolumn{2}{|c|}{ Average final body weight $(\mathrm{g})$} & 2000 & 1960 & & 1910 & 1890 & 68.00 \\
\hline \multicolumn{2}{|c|}{ Average daily weight gain $(\mathrm{g})$} & 43.93 & 43.2 & & 42.14 & 40.36 & 3.00 \\
\hline \multicolumn{2}{|c|}{ Average daily feed intake (g) } & 95.00 & 102. & & 112.00 & 120.00 & 6.00 \\
\hline \multicolumn{2}{|l|}{ Feed conversion ratio } & $2.16^{\mathrm{c}}$ & 2.36 & & $2.66^{\mathrm{ab}}$ & $2.97^{\mathrm{a}}$ & 0.15 \\
\hline \multicolumn{2}{|l|}{ Feed cost $/ \mathrm{kg}(\# / \mathrm{kg})$} & 94.91 & 79.2 & & 65.08 & 53.64 & \\
\hline \multicolumn{2}{|l|}{ Feed cost $/ \mathrm{kg}$ meat } & 308.72 & 273. & & 237.23 & 189.23 & \\
\hline \multicolumn{8}{|c|}{${ }^{\mathrm{abc}}$ Means within the same row with different superscripts are significantly $(\mathrm{P}<0.05)$ different. } \\
\hline Parameters & $\mathrm{T} 1(0 \%)$ & \multicolumn{2}{|c|}{$\mathrm{T} 2(5.0 \%)$} & \multicolumn{2}{|c|}{$\mathrm{T} 3(10.0)$} & $\mathrm{T} 4(15.0 \%)$ & SEM \\
\hline Haemoglobin $(\mathrm{g} / \mathrm{dl})$ & 9.40 & \multicolumn{2}{|l|}{10.05} & \multicolumn{2}{|c|}{10.15} & 9.10 & 0.28 \\
\hline Packed cell volume (\%) & 26.45 & \multicolumn{2}{|l|}{28.15} & \multicolumn{2}{|c|}{28.75} & 25.20 & 0.85 \\
\hline Red blood cell (x10\%/ul) & 2.70 & \multicolumn{2}{|l|}{2.53} & \multicolumn{2}{|c|}{3.02} & 2.64 & 0.10 \\
\hline Mean cell volume (fl) & 97.40 & \multicolumn{2}{|c|}{100.25} & \multicolumn{2}{|c|}{95.10} & 95.35 & 1.31 \\
\hline $\begin{array}{l}\text { Mean cell haemoglobin } \\
\text { concenteration }(\mathrm{g} / \mathrm{dl})\end{array}$ & 35.65 & \multicolumn{2}{|l|}{34.80} & \multicolumn{2}{|c|}{36.30} & 36.05 & 0.25 \\
\hline Mean cell haemoglobin & 34.70 & 36.35 & & 34.5 & & 34.40 & 0.36 \\
\hline
\end{tabular}

Journal of the Faculty of Agriculture and Veterinary Medicine, Imo State University Owerri website: $w$ ww ajol.info 


\begin{tabular}{llllll}
\hline $\begin{array}{l}\text { (pq) } \\
\text { White blood cell } \\
\left(\mathrm{x} 10^{9} / \mathrm{l}\right)\end{array}$ & 9.05 & 9.06 & 9.06 & 9.05 & 0.01 \\
$\begin{array}{l}\text { Lymphocytes (\%) } \\
\text { Neutrophils (\%) }\end{array}$ & 94.00 & 90.00 & 90.50 & 89.50 & 1.25 \\
Eosinophils (\%) & 5.50 & 9.50 & 9.50 & 10.50 & 1.31 \\
Monocytes (\%) & 0.00 & 0.00 & 0.00 & 0.00 & 0.00 \\
Basophils (\%) & 0.00 & 0.00 & 0.00 & 0.00 & 0.00 \\
Total proteins(g/100ml) & 0.00 & 0.00 & 0.00 & 0.00 & 0.00 \\
Albumin (\%) & 2.50 & 4.85 & 5.50 & 6.50 & 0.38 \\
Globulin (\%) & 4.25 & 2.15 & 1.85 & 2.50 & 0.16 \\
Urea conc. (mg/dl) & 4.01 & 4.01 & 3.65 & 4.00 & 0.30 \\
& & & 3.09 & 4.00 & 0.01 \\
\hline
\end{tabular}

${ }^{a b}$ Means within the same row with different superscripts are significantly different $(\mathrm{P}<0.05)$ 